\title{
Postcolonialism and the Feminine in Paulina Chiziane’s O alegre canto da perdiz
}

\author{
Algemira de Macedo Mendes \\ State University of Piauí, Teresina, Brazil
}

\author{
Aurea Regina do Nascimento Santos \\ Federal Institute of Piauí, Teresina, Brazil
}

\begin{abstract}
In this study we present the novel O alegre canto da perdiz (2008), by Paulina Chiziane, focusing on the path of the characters Delfina and Maria das Dores, pointing to the construction of a female speech denouncing the state to which the Mozambican woman was subjected, especially during colonization, a trauma still present in Africa. By telling the saga of these two women (mother and daughter), the novel also makes a reinterpretation of the origin and history of the peoples of Africa. Beyond the issues that mark the secular submission of women to the world of man in certain African societies, Paulina Chiziane also leads us to confront the issue of reductionism practiced by those who look from outside Africa and seeks to present its history and its literature as if the African continent were a single country, as reported by the Nigerian novelist Chimamanda Adichie in her speech against "the danger of listening and repeating a single story, the winners' story” (Adichie, 2009). We aim to identify aspects of the unique feminine of Paulina Chiziane by rescuing legends of matriarchy in the course of the characters. We will also do a reading of colonialism and post-colonialism objectifying the female of writing Paulina Chiziane. The critical placement of the text allows us to analyze it with the contribution of Spivak (2010), Said (1978), Bonnici (2000), among others.
\end{abstract}

Keywords: Paulina Chiziane, O alegre canto da perdiz, post-colonialism, feminine

\section{Introduction}

This article discusses the convergence between literature and postcolonial criticism, contained in the work O Alegre Canto da Perdiz (2008), by Paulina Chiziane.

The discussions conducted here allow us to infer ideas and collaborations about some of the most celebrated positions of the postcolonial critical thinking, especially from authors such as Edward Said (1978), Frantz Fanon (2005; 2008) and Thomas Bonnici (2010).

During the analysis, we observe how Chiziane intersperses the traditional and modern narrative discourse elements, in which a female voice is needed. Her literary writing represents a break from the male chains of literature, analyzed at a symbolic level, and could be well represented by the oppressive and hegemonic power, exposing the female imposition against the male rules and the search for identity.

Algemira de Macedo Mendes, Ph.D. in Literature, Associate Professor, Center of Humanities and Literary Studies, State University of Piauí.

Aurea Regina do Nascimento Santos, M.A. in Literature, Assitant Professor, Department of Teacher Training, Languages and Sciences, Federal Institute of Piauí. 


\section{Paulina Chiziane: A Female Voice in Mozambique}

Paulina Chiziane is the first woman to write a novel in Mozambique. In O alegre canto da Perdiz (2008), she revisits historical events of her nation at the time of Portuguese colonization, and thus builds the narrative addressing complex issues of contemporary reality of Mozambique such as assimilation, miscegenation, ethnical, racial and gender discrimination, clash between cultures, power relations, etc.

The novel has as its protagonist, Delfina, a black woman who resented the fact that her father always has refused to assimilate, convinces José dos Montes, her husband, to become an assimilated, although for this he has to eliminate the traces of his ethnicity and history. Delfina realizes, however, that assimilation is not enough to achieve freedom, deciding then to have a mulatto child. Only then, she thinks, she would be accepted by whites and praised by becoming a participant in the creation of a "new breed" because "only the ones that inherit the complexion of the sailors will be beautiful... So black women seek a mulatto child. To diminish the blackness of her skin” (Chiziane, 2008, pp. 183-184). Delfina then decides to leave the black husband and have children with the Portuguese lover, even still loving José dos Montes. Since she can not comply with the lives of blacks in colonial Mozambique,

Where the culture dictates standards for men and women. Where the money is worth more than life. Where the mulatto is worth more than the black and white is worth more than all of them. Where color and sex determine the status of a human being. (Chiziane, 2008, p. 27)

Discriminated and only desired as a sex object, the description of Mozambican women is always of a creature devoid of intelligence and culture according to the European standards, worthless and voiceless to the colonizing society. These features led to the perpetuation of the image of a devalued woman who influenced other cultures to see the Mozambican women in the same negative way.

In one of the passages of the novel, we can notice this woman who is enslaved, unhappy, heir of the troubles of life and that no longer has hope in her race.

Have you ever wondered what a mother feels when seeing the children leave for slavery? And you, Delfina, you choose the ways for suffering. You're marrying a black man, will give birth to black children and more misfortunes. With so many whites who love you. It costs nothing to delete your race to win freedom. (Chiziane, 2008, p. 101)

Paulina Chiziane's motivation to write is not only because she is a Mozambican woman who talks about women in Mozambique but also because she modifies the scenario usually seen as dominated by man.

She weaves in the present this history of Mozambican women seeking their values in society, the achievement of their ideals along with the affirmation of a Mozambican identity that is the hallmark of female existence in Mozambique. What can be seen on the novel by Pauline Chiziane is the construction of Mozambican identity following a decisive and definitive path that deconstructs the image of a woman who is victim, silent, sexual object, excluded, oppressed and subaltern. Thus, there is a reconstruction of the female image, which after the grief searches to stand up and lift her head turning that subdued space on her domain place; her land, her home, her family, her village and her country.

Thus, the works of Pauline Chiziane develop their key role in the literature of Mozambique building a resistance path and above all self-assertion of identity and especially the presence of Mozambican features in her texts. Paulina Chiziane brings the voice of Mozambican women silenced by repressive circumstances and shows what was hidden in their silence through her works. It is the non-compliance with the situation and the 
desire to change position, to be seen as a woman of value and importance in her own culture. By tracing this path of resistance and identity affirmation in literature, Paulina Chiziane is part of the current female literary trajectory in Mozambique.

About colonialism Frantz Fanon reports that: To colonialism, this vast continent was a wild place, a region infested of superstition and fanaticism, worthy of contempt, full of divine curses, place of cannibals, place of black (Fanon, 2005, p. 245).

By claiming their rights as citizens of the land, Mozambicans triggered a fight not only for identity affirmation, but for national achievement (Fanon, 2005). What was once purely cultural and traditional interest gave way to the national consciousness, what was called the African unity, according to the author.

The right of the woman to be herself is denied for she is a subject in a state of inferiority and female gender, which aggravates the situation. Gayatri Spivak says, "If, in the context of colonial production, the subaltern subject has no history and cannot speak, the subaltern female subject is even more deeply in the dark" (Spivak, 2010, p. 67).

For the author, the recovery of the voice of a subaltern subject, especially the woman's voice, becomes difficult, for always being silenced and differentiated by race and social class: "The subaltern cannot speak. There is no value assigned to the 'woman' as a respectful item in the list of global priorities” (Spivak, 2010, p. 126).

One of the characters in the novel, Serafina, a Mozambican woman who lost her right to give and receive love because she lost all her hopes due to colonial violence, says:

What is love for the black woman, Delfina? Tell me, what is love in our land where women marry on demand and adolescence? Tell me what is love for the woman violated on the street by a soldier, a sailor or a convict? Romantic stories are for those who can dream. The black woman does not play with dolls, but with real babies from the age of twelve. The love and virginity talk is for white women and not for black. [...] That is why for us, black and poor, the love and the passion should be banned. (Chiziane, 2008, p. 96)

Thus, the narrative notifies that for that Mozambican woman there is nothing left but the silenced voice because she had lost her rights with colonization as she is not seen as a woman, as a person, but as a sexual object.

According to Zuleide Duarte de Souza, discussing sexuality in such a plural society is to dive in the ocean where continuously flow into many rivers of bitterness, pain and some joy (Souza, 2013, p. 221).

With colonization, the suffering of Mozambican women with the loss of their enslaved children is also described in the novel:

The end of the black mother is to lean against the door in an eternal cry, before the indifference of the world, placing flowers on imaginary graves of the children we lost. Oh, my Delfina! At this time, I cry for my children lost in the world. [...] It is a useless effort, because the children were taken from me in the prime of life and taken on a boat to unknown lands. Maybe they're alive. Or dead. I feel I will never see them again. And they were beautiful, like this José in front of me. Now I understand the suffering of dogs and goats when we, humans, withdrew their young to destinations unknown to the helpless look of the progenitor. But it will come the day when the whole world will remember the black mother suffering and ask for forgiveness, for the children who were stolen and sold. (Chiziane, 2008, pp. 101-102)

\section{Female Characters in Postcolonial Mozambique}

The author does not make a caricature of her people, but raises them to a condition to reaffirm and value their culture and tradition and denounce the corrupt system that has plagued the nation. She exposes the positioning of a real African thinking: 
I hate these mistresses and wives all mulatto, I hate these pious white women, always willing to work out fine speeches about African women, the suffering, the illiterate, the poor. Where do the roads, plantations and all its grandeur come from? And the beautiful homes, who build them? And the good kitchen? And the white coats, starched, fragrant? From the hands of the damned as José, fruit of the black mothers deliveries. And what we get in return? The scorn, insult, marginality. Who are we black women in this scheme without hope? (Chiziane, 2008, p. 101)

This hopeless regimen is the colonial, slave and prejudiced regimen that marginalizes men and women of Mozambique.

Serafina expresses her pain for losing her children deported because they were black. The pain is so great that she ends up denying her own race in favor of no more suffering for black mothers:

Isn't it enough that your black brothers were convicted and deported to the unknown, never to return? Oh, Delfina, I've cried many tears in this life. Come on, get a white and have mestizo children. They will never be arrested or mistreated, they are free. One day they will also be employers and will take the place of parents and your life will be saved, Delfina. Happy are the women who have children of light skin because they will never be deported. (Chiziane, 2008, p. 97)

Frantz Fanon criticizes the women who want to whiten the race: "Whiten the race, save the race, but not in the sense that we might suppose: not to preserve 'the originality of the world where they grew' but to ensure its whiteness" (Fanon, 2008, p. 57).

Although, Paulina Chiziane also confirms their blackness in her novel, when she recounts the history of her people as a storyteller:

We join the changanes, to ngunis, to ndaus, nhanjas, sixes. We fought and we reconciled. We were invaded by the Arabs, by the Dutch, Portuguese. We fought. The wars of the Portuguese were stronger and ran from one side to another, while the slave boats carrying slaves to the four corners of the world. New wars came. Black against white, and black against black. During the day, attackers killed all but made love on break from fighting. They came with hearts full of hate. But they drank coconut water and hatred turned into love. Women look like coconut, right? The raped women cried the misfortune of pain with seeds in the womb, and gave birth to a new nation. The invaders destroyed our temples, our gods, our language. But they built a new language, a new race. This race is us. (Chiziane, 2008, p. 23)

In this excerpt, Paulina Chiziane uses the pronoun "we" as an identification with the race that does not deny its origin and establishes links or strong ties only in the fabric of a short story. She makes it clear that she not only knows the story, but has an intimacy with the same because she experienced it. Here the themes of identity and resistance are important aspects in the female literary writing of Mozambique, in the works of the writer Pauline Chiziane, and not only that, but they are also key features that together form a circular thinking, where the idea of one takes the idea of the other, the construction of identity, of Mozambican women, living and active and aware of their role in society to which they belong.

The Mozambican identity is not "permanent”, and like any other identity must be constantly built, redesigned, re-signified, and especially be aware of what it represents to itself and to the other with the same identity.

The search for identity must never be finished because it will reveal itself increasingly innovative, especially in search of an identity of the ones who suffered colonization and assimilation of an alien culture. It is now the questioning of those who were colonized and who are trying to rebuild their "reformulated" identities after the period of colonization.

According to Edward Said:

Having been colonized was a lot with lasting, unfair and grotesque consequences, especially after the conquest of national independence. Poverty, dependence, underdevelopment, various pathologies of power and corruption and, on the 
other hand, remarkable achievements in the war, literacy, economic development: this mixture of characteristics marked colonized peoples who had released on one level, but remained victims of their past in another. (Said, 1978, p. 115)

From the perspective of decolonization, postcolonial literature is characterized by national liberation issues, awareness of cultural expression and the attempt to resume civilization as it was before the arrival of the Portuguese in Africa (Bonnici, 2000). The motivation was to reaffirm the traditional values of the people, restore the lost identity during the assimilation phase and wake up to a new horizon, national independence, without further contacts with the dominant imperial culture.

Women's literature has a dual function in the decolonization of acculturated mind because women were doubly colonized, by gender and by race, and through literature they could fight for their rights, were respected and reconsidered within society dominated by men, since imperial rule was over. It can promote and express more faithfully the situation of subaltern, colonized, marginalized women even if what they seek has not been done completely.

Inocencia Mata says:

In fact, in the context of their societies, marked by institutionalized inequalities by legal provisions, and traditional mindset, women writers are a special group both in terms of class and socio-cultural as because of the mastery of writing, which is still a power in Africa. This is the reason why, in a way, these women end up working as spokespersons of this segment of society. (Mata, 2007, p. 421)

Interestingly, the statement of the author when she says that women writers are privileged by master writing. Due to the illiteracy rate is very high in Africa and women are excluded from society, even in the face of difficulties, they were able to have access to literacy and become "spokespersons" of their group. It is seen that they are conquering their space, although it is not easy.

Mozambican women are no longer fighting against domination and the Portuguese colonial oppression, but for recognizing themselves as women, citizens of their country and the legitimacy as a human being.

The double colonization caused the objectification of women in the issue of class and race. Among others, the most effective female decolonization strategy focuses on the use of language and linguistic experimentation. This effective strategy in the decolonization of woman is being achieved through the experimental literature, using appropriate language that can demystify the objectified image of women, give voice to the silenced woman, express their way of thinking, acting and reacting when they are not satisfied with their situation, and the way to fight for the ideal to be achieved, their Mozambican identity.

Today is women who raise their voices and cry out against other slaveries to become singers of dreams (Chiziane, 2008, p. 299).

Thomas Bonnici argues that:

Therefore, the aim of postcolonial discourses and feminism is the integration of marginalized women to society. Similarly to what happened in the reflections of the postcolonial discourse, the first sentence of the feminist discourse concern was the replacement of structures of domination. (Bonnici, 2000, p. 16)

Replacing the dominant structure for a new and authentic structure makes the writing of Paulina Chiziane a postcolonial female literary production, with ideals of decolonization because it narrates women stories of old and current achievements when she opens her mouth and puts an end to silencing by leaving the position of inferiority in the struggle for their freedom.

Even fighting for appreciation of the local culture, the colonized did not realize that both and different 
cultures, the dominant and the dominated, were intertwined in some way. So it is intertwined that when whites have left there was an emptiness:

White Soares left for Lisbon, on the same day, unaware that decades after many whites would follow, leaving behind at the time of the stampede, affection, nostalgia and a magnificent estate, which would be played to stab. My white is gone, what will become of me? I am helpless. No job, no husband, no lover. (Chiziane, 2008, p. 235)

In this passage we can infer that it was beneficial to the economic structure of Mozambican society, in this case the commercial and marketing legacy left by the Portuguese had been kept because somehow the Mozambican culture was already accustomed to those cultural aspects. In the extract above, the character Delfina, a black woman of strong personality, states that she is still dependent on the colonizer. She thinks as white, acts as white, dresses and eats like white, and most of all is black in the same way, with contempt, as well as more assimilate the cultural values of the metropolis, the most colonized escape his jungle. "The more he rejects his blackness, his bush, will be whiter" (Fanon, 2008, p. 34).

It is what it says in the report below:

She had a white man and mulatto children. She already spoke good Portuguese and had cleared by the lotions and wigs. I am black but only on the skin. I am already more than a black, white married! — I'm almost a white, with the lotions that I use. Live like white, like white food and already speak good Portuguese. (Chiziane, 2008, p. 225)

Delfina is black, but her mask is white. For that kind of attitude and behavior Fanon says: "the black who wants to whiten the race is as unhappy as the one who preaches hatred of the white” (Fanon, 2008, p. 26).

The character also completing her thinking, stresses that she does not accept equality between whites and blacks and says:

Will there be, in that freedom you dream, cod and wine? Good clothes? That freedom you speak, Soares, if I am free and I am happy, I'm fine, I have you to protect me? -Freedom, Delfina, freedom. A world where blacks and whites can live in harmony. A world of equality for all. - Oh, Soares, you must be mistaken. A black is a black, white is white. It was God who made the world and put things as they are. And if it happens that freedom, who will clean the house? Who will reap the coconut? Who will take care of my gardens? (Chiziane, 2008, pp. 226-227)

This is seen as an assimilated thought. Delfina no longer considered herself as black, because marrying a white took her to a higher position, she was assimilated. She saw blacks as slaves, poor, miserable, dirty and only needed for work day to day. And freedom would cause her to lose all the perks she had as a lover and as soon Soares' wife.

The process is assimilation, since “[...] the native intellectual [here interpreted as 'native character'] really demonstrates having assimilated the culture of the colonizing power [...] His inspiration is European” (Bonnici, 2000, p. 35). The narrator herself builds a practical view of the problem, and here we find again the post-colonial critique connects to the fiction:

Colonizing is to close all doors and leave just one. Assimilation was the only path to survival [...] Those who do not kneel before the power of the empire could not achieve the status of citizenship. If you do not know the new words you can never be. Come on, swears by all that you will never say another word in that barbarian language. Swear, resigns, kill your tongue, your tribe, your belief. Come on, burn the altars and the old pagan spirits. (Chiziane, 2008, pp. 21-22)

This is how the universe of Paulina Chiziane presents trauma as a consequence of colonization. The possibilities of identity construction are multiple, the old ways are exposed in parallel with new perspectives. It is from this fact that the narrative happens. 
In order to show the position held by Mozambican woman and the impositions of a society victim of colonialism, this study proposed a reflection on gender, race, citizenship and identity, examining social and cultural practices of the Mozambican people. It is seen that the reading of the feminine in Mozambique, from the writer's works requires, in addition to the study of postcolonial feminist ideas that favor a survey about the social and cultural practices of the various ethnic groups that inhabit the Mozambican territory, covered by vast fictional spectrum of work. The narrative of the author is not only focused on women's issues, but also to rethink the values and customs of a society, being clear when it proposes a rethinking of the concepts related to the Mozambican culture, an attempt to show a woman can write her own free destination of male and cultural impositions. Reflecting on the traumas of colonization, slavery and wars in projects of national and community life reconstruction is to think of spaces town and village, past and present.

\section{Conclusion}

Considering the role developed by Paulina Chiziane as an activist for the independence of Mozambique, the empowerment of women and the search for identity, it is noteworthy that she has become one of the most famous Portuguese language writers.

This paper analyzed the representation of female voices in her novel $O$ alegre canto da perdiz observing how colonization affected their lives with slavery and allowing them to live only in the place of the subaltern.

Their voices were silenced for many years but the postcolonial criticism has worked on the reconstruction of their pride, considering the peculiar aspects of their culture, tradition, historical context and the assimilation imposed by the European colonizer.

\section{References}

Adichie, C. (2009). The danger of a single story [Video file]. Retrieved from http://www.ted.com/talks/lang/eng/chimamanda_adichie_the_danger_of_a_single_story.html

Bonnici, T. (2000). O pós-colonialismo e a literatura: estratégias de leitura (Postcolonialism and literature: Reading strategies). Maringá: Eduem.

Chiziane, P. (2008). O alegre canto da perdiz (The merry chant of the partridge). Lisboa: Editorial Caminho.

Fanon, F. (2005). Os condenados da terra (The wretched of the earth). Juiz de Fora: Editora UFJF.

Fanon, F. (2008). Pele Negra, Máscaras Brancas (Black skin, white masks). (R. da Silveira, Trans.). Salvador: EDUFBA.

Mata, I. (2007). A literatura africana e a crítica pós-colonial (African literature and the postcolonial criticism). Luanda: Editorial Nzila.

Said, E. (1978). Orientalismo—o oriente como invenção do ocidente (Orientalism). (T. R. Bueno, Trans.). São Paulo: Companhia das Letras.

Souza, Z. D. de. (2013 April). Dissimular Para Sobreviver: Estratégias de Resistência (Dissemble to survive: Coping strategies). Revista do Núcleo de Estudos de Literatura Portuguesa e Africana da UFF, 5(10), 67-78.

Spivak, G. C. (2010). Pode o subalterno falar? (Can the subaltern speak?). (S. R. G. Almeida, M. P. Feitosa, \& A. P. Feitosa, Trans.). Belo Horizonte: Editora: UFMG. 